\title{
Transparency and Accountability in Local Governance: The Nexus Between Democracy and Public Service Delivery in the Philippines
}

\author{
Arneil G. Gabriel \\ Department of Public Administration, Nueva Ecija University of Science and Technology \\ General Tinio St., Cabanatuan City, Nueva Ecija, Philippines \\ Marc Anthony B. Antonio \\ Department of Public Administration, Nueva Ecija University of Science and Technology \\ General Tinio St., Cabanatuan City, Nueva Ecija, Philippines \\ Vilma B. Ramos \\ Department of Public Administration, Nueva Ecija University of Science and Technology \\ General Tinio St., Cabanatuan City, Nueva Ecija, Philippines \\ Jervin T. Marasigan \\ Department of Public Administration, Nueva Ecija University of Science and Technology \\ General Tinio St., Cabanatuan City, Nueva Ecija, Philippines
}

\begin{abstract}
Transparency effectiveness cannot take place without accountability. Democracy as a form of government necessitates popular support which cannot be given by the people unless trust and confidence to a public institution are maintained. The study discusses the concept of transparency and accountability in the context of a democratic system and its role in enhancing people's trust to public institutions. From the perspective of democracy, the direct link between public service delivery and democracy through the intermediacy of transparency and accountability is established.
\end{abstract}

Keywords: Democracy, transparency and accountability, local governance, popular government, public service delivery, the Philippines

DOI: $10.7176 / \mathrm{PPAR} / 9-7-04$

Publication date:July $31^{\text {st }} 2019$

\section{Introduction}

It is an established dictum in public administration that "public office is a public trust" (The 1987 Philippine Constitution). The strength of a democratic government lies in the trust and confidence of the people. It is the basic foundation that fortifies system of government. The importance of public trust in a democratic government is illustrated in the following excerpts from the thoughts of the great Philippine Jurist Jose P. Laurel thus:

"Democratic (popular) government is a magnificent three-story building: The basic foundation is the people (public); the first story is the Constitution which is the expression of their sovereignty; the second story is the officialdom or a group of caretakers of the edifice; and in the third and highest story is found the altar wherein zealously kept and guarded the mystic fire which symbolizes the faith of the people.

The collapse of the foundation means a destruction of the entire building; the collapse of the second story officialdom-because of the misdeeds or disloyalty, is the demolition of faith of the people; and without faith, no democratic government can ever hope to live and survive" (Jose P. Laurel, Politico-Social Problems)

The relationship between the people and the political system is symbiotic and is akin to a two- way traffic. As a product of a social contract, the government is created to serve the interest and protect the welfare of its people, maintain peace and order and defend the territory from internal and external threats. The government through its mechanisms and instrumentalities delivers public services. The quality, efficiency, and consistency in the delivery of peoples' needs and demands cultivate trust of the people. This general welfare mandate of the government and its performance links democracy to its people. The public as a recipient of social services observes the legitimate orders of the government. The government by its mechanisms implements laws and delivers basic services. Falling short to this symbiotic relationship is a justification to the concept of a "just revolution" pronounced by great teachers Socrates, Aristotle, Rousseau, Locke, and Hobbes (Curtis, 1981).

This paper outlines the relationship that exist between democracy and public service delivery through the intercession of transparency and accountability. The principle, as it is treated by most scholars, believed to generate trust and confidence of the people to the government and its democratic system. However, studies on the linkage between the two variables are commonly presumed if not inadequately supported by the empirical 
undertaking.

The paper tries to establish the link between democracy and public service delivery as they are mediated by democratic governance principles of transparency and accountability. However, the paper is limited to the analysis of transparency and accountability vis -a -vis public service delivery separates from other components of good governance. The interconnection between the twin principle of transparency and accountability as the only variable disregarding the commonly acceptable management belief that other governance principles are necessary to achieve effective and efficient public service delivery.

The first part of this paper is dedicated to providing the conceptual definitions of the terms used. The terms include a) democracy, b) local governance, and c) transparency and accountability including its correlational assumption in democratic system.

The second part tries to explain the status and challenges of transparency and accountability and the mediating role of trust to create public confidence.

The third and last part of this paper is a conclusion that links the principle of transparency and accountability to public service delivery under the regime of democracy and the call to action. What then is the concept of democracy?

\subsection{Democracy is a form of government soliciting public participation}

Democracy refers to an institutional arrangement by which people can participate freely in the political process (Rahaman, 2017). It is a form of government ruled by many (Aristotle in Curtis, 1981) likewise, it is a governmental system characterized by the holding of a periodic election, effectiveness in operation, presence of an impartial justice system and the promotion and protection of civil liberties and individual freedoms (Adetiba, 2018). The great American President Abraham Lincoln defined it as a system of government established "for the people, by the people, and of the people" (Lincoln, 1865). The strength of democracy as a political system and a form of government lies on the strength of its governmental mechanisms that allow popular representation. This system of government may be categorized by the manner it stands for the interests of the public. It can either be a representative democracy where leaders are elected to represent the interests of the electorate in a well-defined political territory or direct democracy where all members of the population can directly participate in the political and governmental affairs without need for the mediation of elected or appointed leaders in the territory selected through periodic election or by the authority of the Constitution (Bernas,1996). The essence of democracy is service to the people (Stanisevski, 2016) in exchange for popular support. It is worthwhile to restate here that "no democratic government can ever survive without the support of the people". The support may come in the form of obedience to laws, or community cooperation to make the government effective and efficient in the performance of its role as development agent of the community (Bryce,1929).

In 1991, with the end in view of establishing participatory democracy, the Local Government Code (LGC) of 1991 was implemented in the Philippines. Its intention among others is to expand the democratic space and to encourage peoples' participation in the countryside development. The new Code not only allows smaller local governments to define to a certain extent its development direction but also to provide an opportunity for the common people to take part in the management of local affairs. A pre-requisite for a strong democratic and participatory government (Palumbo, 2017). Through the implementation of the Local Government Code public participation is encouraged and the government is placed nearer to the community.

\subsection{The LGC of 1991 introduced a system of local governance designed to institutionalize accountability and transparency}

The implementation of the LGC of 1991 introduced a new concept of public management under the guidance of a democratic regime. It is local governance. Democratic governance which institutionalized a system of leadership where programs of government are planned, implemented and evaluated within the locality. Local governance is where the mechanisms, processes, and networks of decision change as they do not depend only to the higher level of political and administrative superiors but more so, to the networks of social political and economic relations within and among the local stakeholders. This made the introduction of local government as a semi-independent, semi-autonomous governmental structure operating under the system of devolution, decentralization, and autonomy. Freeing itself from the traditional total control and supervision of the central government. Therefore, local governance is associated with popular governance and democratic system of public management.

Local governance consists of interactions, processes, procedures within the domains of subnational government intended to maximize benefits for the community. It is a system of local government characterized by a vertical chain of responsibility promoting transparency and accountability relationship between the electorate and the local government (Adetiba, 2017). Local governance implies interactive governing among both governmental and non-governmental actors, often organized in networks (Uhlin, 2016). It is an interplay of political and administrative mechanisms, processes and networks to ensure that society remains intact by 
balancing the interest of the different sectors and transforming them into concrete programs and policies designed to answer needs and demands of the locality.

Decentralization and governance are effective tools to maintain robust democracy, strengthen local government management skill and delivery of public services. Decentralization and local governance are platforms for democracy in terms of quality public service delivery as it moved the center of public services from the central government to the locality where the LGU operates. Decentralization and local governance are administrative inputs to make and enforce rules compatible to deliver services to citizens" (Uddin 2018).

Local governance is synonymous to "democratic governance". It has the features of political values and conducts that promote human rights, eradication of poverty, gender equality, individual freedoms responsiveness, efficiency in government actions, justice, and most importantly transparency and accountability (Cerrillo, 2017).

\subsection{Transparency and accountability is a process in continuum and a major component of local governance}

Transparency and accountability for our purpose is a component of good local governance and is placed in a continuum.

Transparency as a concept is a precondition for accountability. Transparency involves "seeing through" the affairs of local government where information on administrative political and financial decisions of public administrators are known to the electorate. This principle is exemplified by the saying" goldfish in a goldfish bowl" (Nigro and Nigro, 1989) where information on the affairs of government officials and structures are accessible to the internal and external stakeholders. To illustrate the relationship between transparency and accountability, the figure below suggests that transparency per se is not effective without its observance in the day to day operations of the government. However, analysis tells us that the effectiveness of transparency depends on making the information available, accessible, and actionable(accountable). This depends on the matters that have interests to the policymakers, leaders, and the public in general. This paper posits that effectiveness of information can be measured by the manner and degree they are observed by the leaders and government personnel themselves who have the power and prerogative to publish and make the information known to the public clients.

Condition $1 \quad$ Condition $2 \quad$ Condition 3

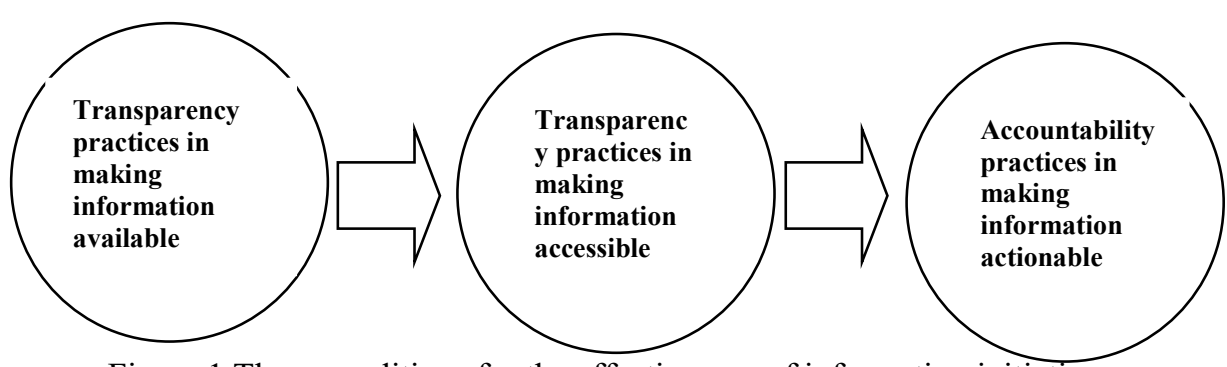

Figure 1 Three conditions for the effectiveness of information initiatives

Source: World Bank (2017 p.248) based on Naurin (2006) adopted in Gabriel (2017)

On the part of the public, they have the prerogative to pick up information valuable to them and make them actionable. Apparently, transparency practices encourage accountability. Henceforth, the level of transparency dictates to certain extent accountability practices.

This information asymmetry provides interest to people having a particular interest in the outcome of the well-publicized information. The information becomes actionable which imposes accountability to a public official to perform. Accountability implies the duty to act in a responsible way and to be accountable to others for one's actions in order to maintain effective and logical links between planning, deciding, action and verification (Ricci, 2016).

In the local context, transparency and accountability is institutionalized by statutory legislations where a person or agency evaluates the action of the government so that it may be held responsible for its actions. In the Philippines, some of the statutes are; The Ease in Doing Business (Republic Act No. 11032); the Anti Red Tape Act (Republic Act No. 9485); the mandatory submission of Statement of Assets, Liabilities and Net Worth and the Code of Conduct and Ethical Standards for Public Officials and Employees (Republic act 6713). These are measures to ensure transparency and accountability in government offices. Through these laws, citizens/consumers are informed of the quality and standard of services they deserve and may demand from public employees such standard of service (Gabriel, 2018). This has a compelling effect on civil servants to meet the expectations of citizens. Accountability is a measure to make local officials responsible not only to their superior but also to the public in general. To establish "sound government frameworks, local officials are made responsible for their decisions and finances to the central government as well as the public" (Uddin, 2018)

Transparency is a critical matter to open up government. Transparency and accountability in local governance inform scrutiny and participation. They need to be embedded in the culture of local governance and 
it is something which politicians and administrators alike should invest considering the key role local governments perform towards countryside development (Gabriel, 2017). Accountability embraces transparency depending on the openness and flow of information between the government and the public. According to Mallya (2016); "the interplay between transparency and accountability is real. He said that "for an institution to be accountable it has to be transparent and if an institution is transparent it is likely that it is accountable as it has nothing it wants to hide". The more transparent the government is, the more accountable the officialdom. Transparency creates expectations among clients leading to "vertical accountability "(Han Y and Demircioglu M.A. 2016). It is a prerequisite to an open and democratic government.

\section{Transparency and accountability as nexus between democracy and public service delivery}

\subsection{Studies on transparency and accountability in the Philippines showed different results}

Transparency and accountability studies in the Philippines yielded differing results. Among the regions of the world, Southeast Asia suffers from low governance scores in observance of transparency, accountability, and other features of good governance (Gabriel, 2017). Within the region, there are inevitable differences from country to country, as well as from one level of government to another. In recent studies generated in the local context, transparency and accountability were proven to be associated with increased legislative performance (Ong and Gabriel, 2018). Whereas, the high levels of commitment to the governance principles in the local level was proven to be incongruent with the actual practice and may require strict adherence to effect positive political outcomes in the local legislative body (Gabriel, 2017). Transparency and accountability are also proven to increase local government performance among component cities in Nueva Ecija, in the Philippines (Gabriel, 2018). On the other hand, some study proved that this governance principle among others, when neglected, creates distrust to public institutions (Brillantes and Fernandez, 2011).

But the majority of the findings point to the fact that observance of transparency and accountability helps develop public trust.

\subsection{Public trust is a function of transparency and accountability practices}

Transparency plays an important role in governance. It is the "accurate mode of assessing the openness, accessibility, and value of government and third-party disclosures which can shape political, economic, and social realities (Heemsbergen, 2016). Transparency is often associated and conflated with "good governance" in Malaysia and Singapore, a variable to increase local legislative performance and a means to improve the quality of legislative service commensurate to public money. However, incongruence of knowledge on the need for transparency and accountability and actual adherence is recorded (Gabriel,2018); yet the twin principles remain effective tools for developing public trust.

The stability of the political system of democracy depends on public trust. The interplay between transparency and accountability encourages citizens' engagement in the government and develops trust and confidence of the people. Accountability conveys an image of transparency and trustworthiness. The mediating role of trust in public institution and democracy cannot be denied. According to Mayers et.al (1995), trust has 3 important factors; 1) competence, 2) benevolence, and; 3) integrity or adherence to sound ethical and moral principles. Trust in a public office is a manifestation of legitimacy and effectiveness of democratic regime and popular support (Hasan, 2018). The absence of transparency may lower the degree of accountability. Lower degree of accountability in the government encourages systemic corruption which would likely cause not only decay in the governmental system resulting in the lost of trust and confidence of the public to public institution thereby effectively abandoning the Constitutional mandate that, "public office is a public trust" ( Gabriel,2018; Cucciniello and Nasi, 2014; Brillantes and Fernandez 2011; Bernas, 2009). Transparency is a mechanism to minimize negative bureaucratic behaviors in the government. According to Benito (2016); it is the act of providing the public reliable information needed to make informed decisions on matters affecting the operation of government. It creates citizen trust and enhances citizens' engagement with the government and improved internal efficiency, promotes open government on a global scale. (Orelli, 2017). Transparency is among the most effective deterrents to corruption in public procurement (OECD, 2014). A clean and transparent government enjoys popular support.

On the contrary, the lack of trust to a public institution is rooted from the unaccountable and unresponsive government, lack of citizen engagement and lack of proper regulation, excessive red tape, corruption, inefficient and ineffective delivery of public service (Brillantes and Fernandez, 2014).

\subsection{The challenges to democracy using the dimension of transparency and accountability}

The challenges of democracy and governing are to promote people's welfare, strategize governance, install good leadership, promotes values and ethics in public services. According to Rahaman (2017), the challenges to democracy are as follows:

1. To reduce conflict of interest. Conflict of interest in service delivery slows down the process and blurs 
institutional mechanisms in order not to be penetrated by external scrutiny.

2. To fight corruption and cronyism. Corruption and cronyism benefit a segment of the public. They are mostly cohorts of the people in power. This may inhibit the public official to open up internal process and mechanism within government institutions creating values to their friends and relatives. Transparency and accountability are not compatible with personal and parochial interests.

3. Improvement of citizens' motivation. It is also a challenge to regain the active participation and enthusiasm of electorates who have been conditioned to receive substandard government service. Transparency and accountability may improve citizens' identification with the government.

4. Protection and respect for human rights and the environment. The fast interface of government operations and the need to meet public needs and demands encourage the public sector to achieve growth and development outcomes in the short possible time neglecting in the process the need to be transparent and accountable.

5. To promote gender equality. The democratic system ensures equality of sexes when it comes to realizing its development goals. The inequality in gender creates inequality in the access to tools and mechanisms for transparency and accountability.

6. Greater Participation of citizens. Democracy is a system of government having its foundation and roots from the community supports. Greater participation of citizens may be cultivated through transparency and accountability.

On the other hand, the mechanisms to face the challenge of democratic governance along the dimension of transparency and accountability include:

1. A clear and articulated planning process open to the public in general;

2. a transparent definition of the internal and external accountabilities and the people who are accountable for what and for whom;

3. an adequate accounting system with less inflexibility and more accuracy;

4. an effective internal system of monitoring and evaluation of government programs and projects;

5. periodic communication of activities was carried out;

6. a significant benchmarking activity and;

7. significant use of technology in the communication process (Ricci, 2016).

\section{Concluding remarks}

3.1 Transparency and accountability have a mediating role between democracy and the quality of public service delivery

Under the Public Choice theory, democratic rule demands increase for better quality government and transparency with accountability is conceived as a precondition for democratic government. Democracy is an institutional arrangement designed to provide services to the people. Its strength rests on popular support generated through trust and confidence of the governed through the intermediacy of transparency and accountability in local governance. As a fair democratic precept, transparency and accountability strengthens democracy, develops trust among its citizens, encourages observance of ethics in public service, and improves public service delivery. Accountability pressures government personnel to improve the delivery of service to the public as they are evaluated on the positive political outcomes of their decisions and the processes to meet targets are scrutinized.

Although transparency and accountability are exclusive concept which requires common conceptual understanding and may be analyzed through the mediating effect of trust to the public institution, transparency and accountability alone improves public service delivery under a democratic political set-up. In fact, it is a prerequisite to a well-functioning democracy that ensures the quality of government performance. Better administrative capacities come about when the public administration works efficiently and effectively. The system of accountability is "one way of securing good quality management." (Kjennerud, 2016).

Inclusive and functional democracy is realized when people take part in the production of public goods. According to Greitens (2016)

"from keeping bureaucrats and policymakers accountable to the public interest, to participating in voting, and other democratic-based processes, citizen participation plays an especially important role in public management. With effective mechanisms of citizen participation in place, public management becomes more dynamic" (Greitens, 2016).

Having this in mind, citizens can participate in the design, creation, and delivery of public service, a hallmark of an inclusive and functional democracy.

Transparency and accountability under a democratic regime are enhanced when "critical effective Egovernment" is established and maintained. The commitment to collaboration, transparency, accountability, and participation in national public governance, ICT infrastructure, adequate human capital, and online service delivery, of effective e-government for a sustainable and desirable future"(Orelli, 2016) is necessary for democratic socialization. In this way, citizens/consumers will be motivated to get involved in the life and 
decision-making process of the local government. The co-production of value and the frequent participation of consumers especially in public service companies will create the establishment of the more active communication process (Ricci, 2016) and a good quality of service delivery.

Governance means transparency and accountability. The compelling effects of local governance (accountability and transparency) and the public ethos it creates make possible the improvement of the quality of services to the public while at the same time strengthening the democratic precept of popular participation through ICT infrastructure. The development of ICT makes democracy participatory and accessible to all. The recent past in governance which placed itself beyond the ambit of scrutiny of the public can now be availed of by the people at no time. ICT transcends political boundaries, time and space.

However, transparency and accountability as nexus to a functional democracy and public service delivery requires commitment more than lip service.

Transparency and accountability cultivate trust which in turn improves the quality of public service. Trust is the very foundation of a democratic government. The loss of trust and confidence of the people because of inefficient and ineffective public service would result in the collapse of the entire edifice symbolizing the democratic system of governance.

\section{References}

Adetiba T.C. (2018). Institutionalizing Democracy. In: Farazmand A. (eds) Global Encyclopedia of Public Administration, Public Policy, and Governance. Springer, Cham

Benito (2016). Accountability and Corruption, Europe. In: Farazmand A. (eds) Global Encyclopedia of Public Administration, Public Policy, and Governance. Springer, Cham

Bernas, JG, (1996) The 1987 Constitution of the Republic of the Philippines: A commentary. Rex Bookstore, Manila Google Scholar

Brillantes, A. B. Jr. and Fernandez, M.T. (2011). Restoring Trust and Building Integrity In Government: Issues and Concerns In The Philippines And Areas For Reform International Public Management Review; Vol. 12, Iss. 2, 2011.Available at www.ipmr.net 55IPMR2011

Bryce L (1929) Modern democracies. Macmillan, New York.

Cerrillo-i-Martínez A. (2017) The Principles of Good Governance. In: Farazmand A. (eds)

Global Encyclopedia of Public Administration, Public Policy, and Governance. Springer, Cham

Cucciniello, Maria, Porumbescu, Gregory A., andGrimmelikhuijsen, Stephan (2016). 25 Years of Transparency Research: Evidence and Future Directions. doi 10.1111/puar.12685

Curtis, Michael (1981). The Great Political Theories, Vol. 1 Avon; Reissue edition. February 1, 1981.

Dang, T.K.P. (2018). Challenges of Forest Governance. In: Farazmand A. (eds) Global Encyclopedia of Public Administration, Public Policy, and Governance. Springer, Cham

Farid, Uddin K. (2018). Decentralization and Governance. In: Farazmand A. (eds) Global Encyclopedia of Public Administration, Public Policy, and Governance. Springer, Cham

Gabriel, A.G. (2017). Praxis in Local Legislative Governance: Measure of Organizational Effectiveness of the Component Cities In Nueva Ecija, Philippines. Available at http://www.apjmr.com/wpcontent/uploads/2017/04/APJMR-2017.5.2.02.pdf

Gabriel, A. G. (2017). Transparency and accountability in local government: levels of commitment of municipal councilors in Bongabon in the Philippines. Asia Pacific Journal of Public Administration, 39(3), 217-223. Available at https://doi.org/10.1080/23276665.2017.1368902

Gabriel, A.G. (2018). Bureaucratic Red Tape in the Philippines In: Farazmand A. (eds); Global Encyclopedia of Public Administration, Public Policy, and Governance. Springer, Cham

Gabriel, A.G. and Ong, Darwin U. (2018) Linking Transparency and Accountability to Local Legislative Performance in the Province of Nueva Ecija in the Philippines. Journal of Public Administration and Governance 384-396. Vol. 8, No 2 (2018)

Greitens, T.J. (2016). Citizen Participation in Public Management. In: Farazmand A. (eds) Global Encyclopedia of Public Administration, Public Policy, and Governance. Springer, Cham

Han Y.and Demircioglu, M.A. (2016). Accountability, Politics, and Power. In: Farazmand A. (eds), Global Encyclopedia of Public Administration, Public Policy, and Governance. Springer, Cham

Hasan, A.R. (2018). Governance and Trust. In: Farazmand A. (eds) Global Encyclopedia of Public Administration, Public Policy, and Governance. Springer, Cham

Heemsbergen, L.J. (2016). Transparency Measures in an International Context. In: Farazmand A. (eds) Global Encyclopedia of Public Administration, Public Policy, and Governance. Springer, Cham

Ingrams A. (2016). Transparency. In: Farazmand A. (eds) Global Encyclopedia of Public Administration, Public Policy, and Governance. Springer, Cham

Linstend,D. and Naurin,M.(2010). Transparency is not enough.Making transparency effectivein preventing corruption.International Political Science Review,31301-332. 
Mallya, Ernest T. (2016). Accountability and Transparency at the Grassroots Level: The Experience of Tanzania

Nigro, Félix A., and Nigro, Lloyd G. (1989). Modern public administration. Available athttps://books.google.com/books/about/Modern_public_administration.html?id=4t8PAQAMAAJ Modern public administration.

OECD (2014). Accountability and Democratic Governance: Orientations and Principles for Development. OECD Publishing, Paris, September 15, 2014. Available at http://dx.doi.org/10.1787/9789264183636-en

Olsen, J. P. (2015). "Democratic Order, Autonomy, and Accountability." Governance 28 (4): 425-440. doi: 10.1111/gove.2015.28.issue-4.

Orelli, R.L. (2016).E-Government, Accountability, and Performance. In: Farazmand A. (eds) Global Encyclopedia of Public Administration, Public Policy, and Governance. Springer, Cham

Palumbo R. (2017) Participatory Governance. In: Farazmand A. (eds) Global Encyclopedia of

Public Administration, Public Policy, and Governance. Springer, Cham

Rahaman M.A. (2017) Governance and Democracy. In: Farazmand A. (eds) Global Encyclopedia of Public Administration, Public Policy, and Governance. Springer, Cham

Reichborn-Kjennerud K. (2016). Accountability and Ethics. In: Farazmand A. (eds) Global Encyclopedia of Public Administration, Public Policy, and Governance. Springer, Cham

Republic Act 7160 (AN ACT PROVIDING FOR A LOCAL GOVERNMENT CODE OF 1991). Available at https://www.lawphil.net/statutes/repacts/ra1991/ra_7160_1991.html

Ricci, P. (2016). Accountability. In: Farazmand A. (eds) Global Encyclopedia of Public Administration, Public Policy, and Governance. Springer, Cham

Stanisevski D. (2016) Minority Groups and Politics. In: Farazmand A. (eds) Global

Encyclopedia of Public Administration, Public Policy, and Governance. Springer, Cham

Stubbergaard Y. and Uhlin A. (2016) Democratic Governance in Developing Nations. In: Farazmand A. (eds) Global Encyclopedia of Public Administration, Public Policy, and Governance. Springer, Cham

The Congress of the Philippines: The Constitution of the Republic of the Philippines | Official Gazette of the Republic of the Philippines. Available at https://www.officialgazette.gov.ph/constitutions/1987constitution/

World Bank (2017).Governance and the law. World Development Report; Washington DC, World Bank.

Lawrence, S. et al. (2001). Persistence of Web References in Scientific Research. Computer. 34, $26-31$. doi:10.1109/2.901164, http://dx.doi.org/10.1109/2.901164

Smith, Joe, (1999), One of Volvo's core values. [Online] Available: http://www.volvo.com/environment/index.htm (July 7, 1999)

Strunk, W., Jr., \& White, E. B. (1979). The elements of style. (3rd ed.). New York: Macmillan, (Chapter 4).

Van der Geer, J., Hanraads, J. A. J., \& Lupton R. A. (2000). The art of writing a scientific article. Journal of Scientific Communications, 163, 51-59 